\title{
Understanding Teachers' Beliefs, Perspectives and Aspirations toward Quality Education
}

\author{
Nilda W. Balsicas, Jonathan R. Adanza \\ St. Dominic College of Asia, Bacoor City, Philippines
}

\begin{abstract}
This study examined and analyzed the teachers' beliefs perspectives and aspirations in improving quality education. A survey questionnaire on the ten traits of highly effective schools suggested by McEwan was used [14]. Open-ended questions on faculty's beliefs in improving quality education were also asked. Semi structured interview was also conducted. Findings include views that the institution has the qualities of a highly effective school; teachers' belief that professional development should be given premium by the institution to improve the quality of education; envisioned graduates who are globally competent, research oriented, among others. Themes on personal beliefs of teachers include Teaching is facilitating, evolving and innovating, simplifying and being flexible, putting together transmitting and demonstrating, preparing among others. The themes emerged show how wisdom penetrated the mindset of teachers, expressed through their beliefs and perspectives. Implications include the strengthening of research activities and involvement of the stakeholders in improving the quality of education.
\end{abstract}

\section{Introduction}

Generally, quality education is the currency in higher education institutions. It is always equated with improved student achievement and said to steer enrollment to a high peak. It is oftentimes seen in most academic institutions' vision or mission. But what is quality in education? What are the features of reputed quality college and universities? Each institution has its own standards of quality education. Sometimes quality in education is contextual. For instance, in the Philippines, a higher education institution's quality education is demonstrated by exceeding the minimum standards of the Commission on Higher Education, or meeting beyond the requirements of an accrediting agency or industry. In some instances, immediate employability is primary the hallmark of quality education of a higher education institution. According to UNESCO, 2004 [2], educational quality requires relevant content, since imported or inherited curricula have often been judged insufficiently sensitive to the local context and to the learners' socio-cultural circumstances. Similarly, UNICEF states that quality education includes: Content that is reflected in relevant curricula and materials for the acquisition of basic skills, processes through which trained teachers use child-centered teaching approaches in wellmanaged classrooms and schools and skillful assessment to facilitate learning and reduce disparities; outcomes that encompass knowledge, skills and attitudes, and are linked to national goals for education and positive participation in society [8]. But Beeby [2] argues that quality judgments differ from one another in terms of the goals set. Similarly, there is an accumulating convergence of research that calls for assessments of quality in education based on local stakeholders' understandings while Muhammad Imran [15] mentioned that it is not always easy to arrive at a commonly agreeable definition of quality of education. It is equally difficult to quantify the notion of quality in education.

In the Philippines, quality in higher education institutions remains a challenge particularly in the ASEAN 2015 integration. Some of the challenges have something to do with meeting the stated mission and goals, local or international; others have something to do with the qualifications of the faculty and laboratories. St. Dominic College of Asia is not spared from the academic and economic challenges that go with the ASEAN 2015. Thus, in 2010, the College embarked on program accreditation in which seven out of its 14 programs are Level 1 accredited and the accreditation process continues up to this date.

Given its differing views on quality education, it might be useful to draw out the meaning and concept of quality education from teachers' beliefs, perspectives and aspirations. Teachers have always been the direct contact of the students in terms of academics and in preparing for lifelong learning. They have direct influence in the implementation of the mission and values of the institution, and they share the value of evaluating schools [13]. By understanding their perspectives and personal teaching beliefs, we are able to define quality education or quality teaching at a local school. This study reports the teachers' perceptions of highly effective schools, their views and aspirations of a quality school and their personal teaching beliefs in the local setting.

The data obtained are viewed as indirect suggestions for their beliefs, views and aspirations of 
quality education. They provided a glimpse of how teachers view the institution's qualities based on McEwan's traits of highly effective schools [14]. As what Ingvarson and Rowe [3] asserted, what teachers suggest and should be able to do are measures of teacher quality and quality education. In the same way those teachers' beliefs have been viewed as a key area that needs to be addressed in the context of most educational reforms [4].

\section{Research on Teachers' Beliefs, Perspectives and Aspirations}

Although there are a number of studies on teachers or educational beliefs, these are focused more on the discussions and debates about teaching and learning practices or focused singly on teachers' beliefs [16]. These gaps in the literature indicate that, to date, there had been limited exploration on teachers' beliefs in the context of improving quality education. Thus, this study was conducted. The study reported in this paper was designed purposely to investigate the teaching beliefs, perspectives of quality schools held by a group of teachers whose programs underwent accreditation. The study on the teachers' beliefs and views is significant and relevant because it defines the level of motivation and aspirations [7].

Teachers beliefs are developed in many ways: some may have come from experiences; others may originate from his knowledge or the way he/she views the world he/she is in. This is corroborated by Lortie. According to Lortie [7], teachers' beliefs may emerge from personal experience, values, social encounters, community participation, popular culture, teacher preparation, observing teachers, or professional development. At the most global level, teachers hold beliefs about the purpose of schooling. For some teachers, these beliefs are rooted in a holistic perspective wherein the purpose of education is to help students reach their full potential in every facet of their lives. Other teachers' beliefs are rooted in more essentialist models that position schools as source of knowledge for students to become responsible citizen and lifelong learners in the society. In short, teacher beliefs are varied and constructed from a context and different experiences.

Teachers' beliefs are relevant in the improvement and effectiveness of schools [19]. Similarly, teachers' beliefs that school should respond to the changing educational reform to improve quality education is corroborated by Valli and Buese [20]. They mentioned that schools should adapt to changing educational reforms, and in the same way that teachers should adapt those reforms both in their classroom and out-of-classroom tasks. As what Richardson [10] stated, "beliefs are thought to drive actions, experiments and reflection on action may lead to change and/or addition to beliefs" (p.104).
In the EQAO report, it cited Fine who asserted that educators, such as teachers, generate belief systems because they need to explain their efforts in ways that give them a sense of accomplishment. These belief systems may help educators feel more successful, but may also prevent them from imagining what could be. It mentioned that only Teachers can put forward their role in improving quality education by internalization of their contextual beliefs. Similarly, Brophy and Good [17] said that better understanding of teachers' belief system or conceptual base will significantly contribute to enhancing educational effectiveness or quality education. Belief systems are described as dynamic in nature, undergoing change and restructuring as individuals evaluate their beliefs against their experiences.

\subsection{Conceptual Framework}

The concept of the Traits of Highly Effective Schools by McEwan, Lorties's concept of Teacher Beliefs, and Senge's The Fifth Discipline System Thinking guide our interpretations for this study. To explicate the concept of teachers' perceptions of highly effective schools, we used the concepts of the Ten Traits of Highly Effective Schools by McEwan. She wrote that strong instructional leadership, research-based instruction, clear academic focus, high level of relational trust, strong collaboration, high expectations, opportunities to learn, alignment of curriculum, instructional approaches, and assessments, student achievement, and high levels of accountability are the traits of improved schools.

To elucidate further teachers' beliefs, the concept of Lortie [7] is also used. Lortie stated that teachers' beliefs exist on many levels from global to personal and serve as overarching frameworks for understanding and engaging with the world. They can guide teachers in understanding new experiences. Senge et al. [18] premised that schools can be "made vital, sustainably renewed by involving everyone in the system in expressing their aspirations, building their awareness, and developing their capabilities. In short, teachers can marry their aspirations with better performance over the long run". System thinking is a blueprint for how organizations can innovate and change through integrating all aspects of the college. In it, the performance of the whole is greater than the capabilities of its individual parts [12]. The integration of the quantitative and qualitative data fortified the presupposition of the study.

\section{Methods}

\subsection{Research Design and Context}

This study used a multi-method method [1].Colin [5] cited the Sequential transformative design which 
is characterized by the use of either qualitative or quantitative method. The study is also a case of a tenyear old higher education institution. The Philippines' current educational reforms drive higher education institutions to improve standards to develop a quality nation. Accreditation is a factor that changes the landscape of the academic institutions by continuously improving standards. St Dominic College of Asia (SDCA) in Bacoor, Philippines is one of the higher education institutions which were granted Level 1 status by the Philippine Association of Colleges and Universities Commission on Accreditation (PACUCOA) in just ten years of its existence as a College.

\subsection{Research Instruments and Samples}

To assess the perceptions of the teachers on the Ten Traits of Highly Effective Schools, we used the McEwan questionnaire. It contains ten traits of highly effective schools. Each item was rated on a 5point Likert-type scale ranging from not at all (1 point) to strong (5 points). An open ended questionnaire was also given to the teachers. It contained questions which focus on how they can improve themselves professionally, in what ways can they attain the institution's vision, and how they envision a graduate of the institution and their personal teaching beliefs.

All teachers involved in the accreditation were given the survey questionnaires on highly effective schools. Out of 82 teachers, only 75 were able to return the questionnaire. Teachers from the Nursing (13), Hospitality Management (10), Business (7), Information Technology (6), Psychology (6) and Education and Arts (23) departments participated in this study. Out of the 75 participants, 10 were interviewed.

\subsection{Data Collection and Analysis}

Both quantitative and qualitative methods were utilized to collect data for this research. Based on the teachers' answers to the open-ended questions, the teachers were interviewed to validate their answers. All interviews were recorded and transcribed verbatim. All qualitative data were interpreted using content analysis. In mixed methods studies, investigators intentionally integrate or combine quantitative and qualitative data rather than keeping them separate. This integration can be achieved by reporting results together in a discussion section of a study, followed by qualitative quotes or themes that support or refute the quantitative results [6].

\section{Findings}

\subsection{Quantitative Data}

Table 1. Mean and Standard Deviations of Teachers' Perceptions of the Qualities of the Institution

\begin{tabular}{|l|l|l|l|}
\hline $\begin{array}{l}\text { Traits of Highly } \\
\text { Effective } \\
\text { Schools }\end{array}$ & $\begin{array}{l}\text { Mean } \\
(\mathbf{n = 7 5})\end{array}$ & SD & Interpretation \\
\hline $\begin{array}{l}\text { Opportunities to } \\
\text { Learn }\end{array}$ & 4.286 & 0.667 & $\begin{array}{l}\text { Very } \\
\text { strong }\end{array}$ \\
\hline $\begin{array}{l}\text { High } \\
\text { Expectations }\end{array}$ & 4.257 & 0.817 & $\begin{array}{l}\text { Very } \\
\text { strong }\end{array}$ \\
\hline $\begin{array}{l}\text { Clear Academic } \\
\text { focus }\end{array}$ & 4.257 & 0.817 & $\begin{array}{l}\text { Very } \\
\text { strong }\end{array}$ \\
\hline Alignment & 4.086 & 0.919 & Strong \\
\hline Accountability & 4.086 & 0.742 & Strong \\
\hline Collaboration & 4.057 & 0.725 & Strong \\
\hline $\begin{array}{l}\text { Instructional } \\
\text { Leadership }\end{array}$ & 4.029 & 0.923 & Strong \\
\hline $\begin{array}{l}\text { Results } \\
\text { students' } \\
\text { achievement }\end{array}$ & 4.0 & 0.907 & Strong \\
\hline Relational trust & 3.971 & 0.857 & Strong \\
\hline $\begin{array}{l}\text { Research-Based } \\
\text { Instruction }\end{array}$ & 3.8 & 0.901 & $\begin{array}{l}\text { Moderately } \\
\text { strong }\end{array}$ \\
\hline
\end{tabular}

Based on the results, the perceived strengths of the school were identified. Except for researchbased instruction, majority of the traits were rated highly implying that the college possesses the traits of highly effective schools [14]. The research-based instruction trait is not so strong, implying that the college has still room for improvement. The results are corroborated by the interview data.

Among the traits, "opportunities to learn" (M4.286; SD-0.66) obtained the highest mean and interpreted as very strong. It means that the College provides students opportunities to learn by providing highly effective teachers and ensuring that students are exposed to various meaningful learning and activities. Consider this statement from Faculty A:

"I want to maintain if not exceed my last year's excellent rating in student evaluation.

Thus, I make sure that I provide more and varied student-centered activities... “"

The faculty rated the College with both strong "clear academic focus" and "high expectations" (M-4.257; SD-0.817). During interview, majority believed that 
the College has attained its Level 1 accreditation status because of strong 'clear academic focus. Other faculty mentioned that strategic articulation of the vision, mission, goals and core values of the College plays also a major role in attaining the level 1 recognition at an infancy stage of the institution. As a matter of fact, the College arrived at common core competencies expected from students. The set of core competencies is known as R M2USIC4. - which stands for research and product development, multicultural advocacy, moral and spiritual accountability, understanding the discipline, selfdirected learning, information and technology literacy, communication skills, critical thinking, community engagement, and creativity and innovation.

Similarly, faculty members have high expectations of their students' capability. These expectations are demonstrated in a holistic manner of implementing the curriculum. When Faculty $\mathrm{C}$ was interviewed he mentioned this:

\begin{abstract}
"Although the College is still at its infancy stage in the outcomes-based education approach, it becomes the forefront of my beliefs. For example, although there are students who have different abilities, everyone is capable of achieving. This is why learner-centered activities and authentic assessment are part of my syllabus."
\end{abstract}

Both "alignment (M-4.086; SD-0.919) and "accountability" (M-4.086; SD 0.742) traits" were perceived as strong traits by the faculty. This could be attributed to the curriculum and instruction related activities that all faculties do in and outside the class. For example, a faculty becomes a curriculum enhancer because he/she is expected to submit a report from the weekly plan. He accounts his own performance against the curriculum prepared by him or by the curriculum developers. A faculty member is accountable to the implementation and enhancement of the curriculum, thus expecting improved student outcomes. To sustain teaching excellence as part of the mission of the college, it annually allocates substantial funding for faculty development. Every school sponsors an average of eight seminars or conferences every term.

Collaboration (M-4.057; SD-0.725) is perceived as a strong trait of the College. Manifestations of its strength include the cross- department activities in community outreach, lecture series and even researches. For example, when the community research office announced that it is resuming its annual mangrove planting to a newly acquired 2hectare coastal area, all departments immediately enlisted their services which resulted in the planting of about 3,000 seedlings within the day. Strong collaboration is also evident when faculty members willingly offer their expertise to mentor a faculty or student, either from different disciplines or within the discipline beyond the call of duty. Thus a faculty in General Education revealed this:

\section{"...I believe I have a commitment to our mission as a teacher. When I was asked to conduct remedial classes, I willingly accepted it because I want to help my students. Even if mentoring is beyond the agreed contract, I am still willing do to it particularly if I can see that my students' skills are still behind standards..."}

The "Instructional leadership (M-4.029, S.D. 0.923)" trait is perceived as strong. The key factor that keeps the College going strong and competitive is the presence of transformative leaders. The academic heads ensure that they set the tone for the directions of the respective schools. Our academic heads are qualified experts in their field of specialization, and they possess what Ewan called an intensity component-assertiveness - that encompasses personal attributes like self-confidence, self- differentiation, and character. As a matter of fact, one of the academic heads is a national awardee for teaching excellence.

Faculty members perceived "results of student achievement (M-4.0; SD-0.907) "as another strong quality of the institution. Getting hundred percent passing rates in licensure examinations given by the state and getting employed immediately after graduation, and favorable feedback from the industries are few of the barometers that the College uses as hallmarks of improved student achievements. All faculty members are unwavering in their desire to arrive at the expected student outcomes. For instance, every end of the term data from the Syllabus Implementation Review and Student Evaluations are used as bases for curriculum improvement and faculty development. Strong "relational trust" (M3.971; SD- 0.857) trait of the college is being demonstrated by giving unequivocal support to all members of the College. Consider the thoughts of a pioneer faculty.

\section{"I have been here since the College started. Until now, I can still feel the sense of community ...camaraderie because everyone is trusted to perform the assigned tasks. I feel important when the president himself dropped by and asked about my work, I thought it is amazingly fulfilling...that uplifts my spirit to improve my craft..."}

The lowest rating was obtained in "researchbased instruction (M-3.8; SD-0.901)" trait. Faculty members are well-rounded individuals, well-trained, highly motivated, and masters of content, they attend 
seminars and conferences to improve their professional competence. But they do not perceive themselves as "research-for-scholarship" experts, meaning capable of publishing research results. They still believe that they are still in the gateway to become experts. But they argue the notion that they are not highly effective teachers. Faculty E stated her point:

\begin{abstract}
“...faculty members do not attend classes unprepared; we are clear about what we intend to accomplish using our syllabus and weekly plan...we improved also our syllabi and activities based on the comments of the students and our own observations, from the seminars and readings...even the suggestions of the industry and the on-the-job establishments are used to improve our content and standards. But you know there are a handful of faculties who are strong believers of their own "time-tested styles", meaning, they still refute that the traditional lecture is better than using a repertoire of student-centered activities in improving student achievement..."
\end{abstract}

\subsection{Findings from the Qualitative Approach Teachers'}

\author{
Aspirations 1. Desired Area for Professional \\ Growth
}

Professional growth is one of the most significant objectives that a faculty should achieve aside from one's role as a teacher in the teaching-learning process in any given situation and setting. The study yields six areas in which the faculty felt the desire to grow professionally: communication, research, educational guidance and counseling, outreach program, use of technology and appropriate skills, leadership and management, and practical skills. For instance, Communication is an important area in which the faculty felt the need to grow and develop, particularly in dealing with other people outside one's discipline. One nursing faculty confided by saying, "I would like to grow in the area of communication. It is because I would like to have confidence in communicating with other people outside nursing." The faculty knows that when a teacher is a good communicator, one's confidence is boosted and this would give one the needed empowerment and confidence to be with other people outside one's circle of influence. Research was also identified to be an area for a faculty to grow, develop and be competent with. Relevant to it is research application particularly evidence-based practice. One participant expressed herself by saying, "I personally would like to grow professionally in research area since I believe that research is a key factor in the academe and needed by the faculty members." Moreover, relevant to research, the participants also identified indicators of research-oriented and research- cultured teachers.

Teachers' Aspirations 2. Ways to Help the Institution Realize Vision, Mission and Objectives

There are many ways, aside from rendering quality instruction, that a faculty member can help one's institution realize its Vision, Mission, and Objectives. However, the participants highlighted the following: involvement in community outreach and service programs, doing research, taking part of different organizations within the school, fulfilling duties and responsibilities as faculty, and good governance. The participants see involvement in community extension and services as very important in an institution which emphasizes community service like SDCA, aside from instruction and research. When asked about ways, aside from rendering quality one faculty answered: "Continue the community service programs, projects and activities of the school and develop it more according to the needs of the communities." One faculty expressed the same tone when she said, "[I can help SDCA realize its VMO] through active participation in the institution's periodic community outreach and research programs...."

Teachers' Aspirations 3. Vision of SDCA Graduates

The faculty envisions the students of SDCA four to five years from now to be: locally and globally competitive; competent, empowered and gainfully employed; research-oriented; competent leaders; virtuous graduates. When asked about how they envision the SDCA graduates 4-5 years from now, the faculty identified local and global competitiveness at the forefront. Competitiveness for them entails readiness to face the challenging world of competence, in which there is no place for the mediocre and even the average performers to thrive. Graduates should be competent, assertive and articulate to be globally competitive. One faculty member noted, "[I envision the graduates to be] globally competitive in the careers that they want to pursue in the future." One theme that came out from the narratives of the faculty is their vision for the graduates to be competent, empowered and gainfully employed. To be competent is to become experts and excel in their fields of specialization; to become effective communicators who comprehend and express knowledge, thoughts and feelings in a variety of ways. They are also dignified, empowered professionals who are gainfully employed in reputable institutions. This is extracted from a participant who quipped by saying, "I envision SDCA graduates having successful career. 
Successful career [is] not only measured [by] being employed but excelling [in] the field of endeavor." One faculty exactly reverberates this idea by stating, "I envision an SDCA graduate 4-5 years post graduation as a professional who is empowered, gainfully employed either in a reputable institution or as an entrepreneur who is competent excelling in his/her field of specialization." This competence and empowerment is not only for their own aggrandizement but also to help in nation building as one faculty rightfully puts it, "...ready to face the challenging world of competence and join the population for stronger nation [emphasis ours]."

\section{Integration of Quantitative and Qualitative data}

In the survey, Research-based instruction obtained the lowest rating among the traits of highly effective schools. It is interpreted as a moderately strong trait of the institution. This means that Research-based instruction delivered by highly effective teachers seemed not the core of the school before Level 1 status. Said result is corroborated by the themes that emerged from the interview. In the area of professional development, Research was also identified as an area for a faculty to grow, develop and be competent in. Relevant to it is research application particularly evidence-based practice. One participant expressed herself by saying, "I personally would like to grow professionally in research area since I believe that research is a key factor in the academe and needed by the faculty members." Moreover, relevant to research, the participants also identified indicators of researchoriented and research-cultured teachers. They are knowledgeable of the latest issues and trends regarding one's discipline, as well as module and book writing. Interestingly, doing research is also the teachers' way of helping the institution attain its vision. Research and its related activities are expected to be implemented in the classroom settings as part of the teachers' role to realize the vision to produce research-oriented graduates. In the other themes, teachers commit to doing research and envision a graduate who is research oriented. This means that their activities will pave the way for making the research as one of the core activities of the teachers.

The high rating of the "opportunities to learn trait" is expected of each faculty at SDCA. This means that the institution provides students with opportunities to learn from highly effective teachers in every classroom, along with differentiated and scaffold opportunities to learn as needed for all students to achieve academic success [14]. This is supported by this statement: Fulfilling duties and responsibilities as faculty is more than just teaching well and imparting knowledge and wisdom to students in the form of classroom instruction, "[providing] instructional materials for the students," and "offering workshops and seminars to students," but as a faculty asserted, "becoming a role model for the students," which means to a faculty to "walk the talk" and "[to inculcate] to every student loyalty toward the institution." One faculty likewise shared that to help the institution achieve its VMO, the "faculty should be openminded and honest," basically the characteristics of a good teacher who does one's job with a sense of responsibility and accountability. One faculty specified her own planned program and said, "I can help my colleagues to update themselves about technology or any IT subjects which can help in their tasks." Good governance can similarly be expressed by a faculty through close monitoring as one faculty emphasized, "I would do my best to help out in monitoring if VMO is being practiced by my colleagues as well as the students."

The high rating of the "high expectation trait" is expected of each faculty at SDCA. The high perception of the teachers toward this trait is supported by this assertion from a faculty: Taking part in different organizations within the school was identified as one of the things that the faculty can help a school to meet its VMO. This is not only joining organizations but according to a faculty, "being involved in any activity" not only inside the school but even to "represent the school". Therefore, taking part may also include becoming a representative of the school to the outside activities to "improve partnership with outside agencies, parents, and communities".

The high ratings in curriculum and assessment alignment as one of the traits of the College demonstrated that SDCA faithfully adheres to its objectives. Thus, one of the major activities in most of the courses is research. Each student is expected to undergo research early in his college life. This is also brought by what the institution has been advocating and enforcing. There are faculty members who showed needed alignment to the primacy of research in their institution as they underscored research as an attribute of a successful graduate in the next four or five years. One faculty said it, "Graduates...are globally competitive, dynamic and research-oriented [emphasis ours] armed to the needs of any institution committed to serve locally and internationally." This is corroborated by a hospitality management professor who said, "I envision the future graduates of SDCA to be dynamic and proactive individuals, graduates with love and passion in research [emphasis ours]...."

The "Accountability" trait was also highly rated by the teachers because the College ensures that evaluation of the curriculum and teaching approaches by all concerned faculty and chairs is conducted every end of the term. One faculty exactly 
reverberates this idea by stating, “...by periodically evaluating our curriculum content and approaches, we can assure our stakeholders of competent future professionals..." He further said: "I envision an SDCA graduate 4-5 years post graduation as a professional that is empowered, gainfully employed either in a reputable institution or as an entrepreneur who is competent, excelling in his/her field of specialization." This competence and empowerment is not only for his/her own aggrandizement but for nation building. As one faculty rightfully puts it, "...ready to face the challenging world of competence and join the population for stronger nation [emphasis ours]." Accountability is also express in terms of how a faculty exerts effort to improve oneself as one of the faculty posited that a faculty like him should also never stop learning. As he said, "one should continue post- graduate studies."

The high rating of the teachers to the "collaboration trait" demonstrated the belief that the teacher's vision of the graduates is itself an ongoing collaboration between the teacher and the student. Consider this statement: The faculty sees graduates to become competent leaders in their respective fields and in their communities. Competence in this context may mean for the participants to "[excel] in the field of endeavor like becoming managers, business owners, consultants and even local government officials." This further implies holding higher positions in an institution they are going to work for, as the faculty participants are referred to as "great leaders excelling in their respective fields."

The high rating to "instructional leadership trait" demonstrated their appreciation to constant monitoring supervision by the academic heads. With regard to the interview data, there is no direct support generated during the interview. What is interesting is their desire to become instructional leaders and wanting of professional development in leadership. Consider this statement: The faculty members felt the desire to improve in the field of leadership and management particularly in the areas of decision-making, supervision, planning, leadership and accountability and operations management including industrial security management. One faculty emphasized this by asserting, "Leadership and accountability are very essential to employees' growth and development. Having this experience will hone my capability to manage and learn new things."

Teachers' rated highly the "Students' Achievement trait". The College is known for its student achievement including but not limited to continuously improving results on measures of accountability established by the Commission on Higher Education (CHED). This is another case of being highly rated but themes that emerged were not supporting nor refuting the institution's qualities.
Consider this statement: When asked about how they envision 4-5 years from now the SDCA graduates, the faculty identified local and global competitiveness at the forefront. Competitiveness for them entails readiness to face the challenging world of competence, in which there is no place for the mediocre and even the average performers to thrive. Graduates should be competent, assertive and articulate to be globally competitive. One faculty member noted, "[I envision the graduates to be] globally competitive in the careers that they want to pursue in the future." Teachers' rated highly the "Relational Trust trait". The interview data corroborated the teachers' rating. Consider this statement from a faculty: “... aside from rendering quality instruction, I wanted to develop program for the students as well as faculty [for them] to realize their worth, hence the realization of our VMO."

The overall ratings of the teachers on traits of highly effective schools and the interviewed data are viewed as demonstration of their beliefs. The beliefs of the teachers and their perspectives are related to what Hehir and Katzman [14] termed as products of a collaborative problem -where teachers work together a good deal both within and outside the classroom in delivering the curriculum and in ways their school can improve quality education where it continually confronts new challenges (p. 53-59).

\section{Personal Beliefs of Teachers}

Theme \#1: Teaching is facilitating

Teachers believe that teaching is a matter of facilitating the class to learn and not just to transmit knowledge from the textbook to their notebooks. One teacher makes this explicit when he asserts that teachers are facilitators of learning among students.

Theme \#2: Teaching is evolving and innovating

A language professor shares that teaching is an evolving process, hence the need for innovations. What is appropriate for today may be out of style the next day. Each day is a challenge yet also an opportunity for teachers to metamorphose into the best teachers they can be, given diverse situations. In the process, teachers innovate themselves constantly to maintain their relevance to their students, taking into account the evolving nature of students today.

Theme \#3: Teaching is simplifying and being flexible

Moreover, another language professor believes that teaching entails simplifying contents to suit the kind of learning situation one is into. Likewise, a teacher needs to be flexible in all his/her undertakings. However, capability to simplify 
content entails a deep understanding of the subject contents. Knowledge and experience, therefore, are the keys to make this a reality. As one participant aptly puts it, "Teachers are knowledge providers, [and] hence, they should be well-experienced and academically prepared to teach the subjects." Not only is content simplified but how a teacher should approach at teaching is also considered. A Psychology teacher asserts by saying that quality instructions does not go with tremendous paperwork as one loses sight of the main reason why a teacher is in the position and that is to teach students.

Theme \#4: Teaching is putting together

Putting together comes in different forms for teachers. One Political Science professor argues that quality education could be realized if expertise of teachers, a good quality curriculum, and the school's system work hand in hand. For her, quality education is a unified effort of many factors. A Business Management professor adds to this by arguing that if SDCA teachers incorporate the core values of the institution which are service, dynamism, competence and accountability, the institution can produce quality graduates in the years to come. For a Hospitality Management instructor, learning entails repeated application of ideas and theories into practice, that is putting all together in equilibrium the main components of teaching and learning-theory and practice.

Theme \#5: Teaching is transmitting and demonstrating

The modern student-centered paradigm of teaching failed to obliterate the traditional paradigm of teaching which is teacher-centered. As a Science professor emphatically contends. The teacher's main role is transmission of information and demonstration of correct solutions and to ensure that learning is well- structured. This argument is plausible for Physics and Biology professor as concepts in these disciplines are difficult to grasp with the raw understanding of regular students.

Theme \#6: Teaching is preparing

Preparation is always a factor in quality teaching as underscored by some of the participants. For a Science professor, learning should be wellstructured. Good teaching and learning occurs in a well-structured environment. The learning milieu needs to be prepared for it to become conducive to learning. For a Psychology professor, preparation means constantly updating the content of the curriculum. He further posited that quality instruction needs ample time for teachers to prepare. Alluding to the school's preparation for accreditation, he further asserted that quality instruction does not go with tremendous paperwork. To a Chemistry professor, teachers should always be academically prepared to teach. Preparation never stops with formal education in college or graduate school. As a Management professor said,

$$
\begin{aligned}
& \text { "...preparation motivates a teacher to be } \\
& \text { open to new ideas, new strategies and } \\
& \text { updates in their field or profession. This can } \\
& \text { be achieved by attending seminars and } \\
& \text { conferences relevant to one's discipline." }
\end{aligned}
$$

Theme \#7: Teaching is molding

Participants believe that the learner is the most important person in the learning environment. There is no greater task for teacher than to mold and shape the learner to be somebody who can respond positively to the challenges of global competition and relevance. A Psychology professor strongly puts his teaching belief that teachers should teach with passion and mold students become practitioners in the future, like him. Indeed, teaching is multiplying one's kind. In molding and multiplying, a teacher must provide and deliver the best learning. To a teacher, it is basically allowing the students do their parts as learners and being realistic of the outcomes. Like the first belief which is teaching is facilitating, molding is a collaborative effort between teachers and students.

\section{Theme \#8: Teaching is adapting}

Adapting to ever changing context is of paramount importance to a teacher. A Business Management teacher believes that the teaching context should be conducive to learning. Moreover, learning equipment should be checked and maintained regularly. Teaching context needs to be understood for teachers to be able to adapt and use this context to one's advantage. Adapting is not only in the micro level but also in the macro level. As Mathematics professor has it: "Curriculum should adapt to existing trends of the economy of the country." As part of the curriculum, teaching plays an important role in this adaptation process.

Theme \#9: Teaching is giving feedback

Communication and giving feedback are important factors in every institution and profession most particularly in teaching. A Nursing professor notes that proper communication and dissemination of feedback from students are important in the teaching and learning process. Teachers need feedback from students and students also need feedback from teachers as another Nursing professor adds. 
Theme \#10: Teaching is individualizing

A Psychology teacher explains that there are different paradigms for regular and special education teaching. Teaching should be individualized not only to Special Education students but also to all types of students across age, gender, status and discipline. This is further explicated by a Science teacher who quips, "I do believe that practicing [various] teaching approach[es] will be much appropriate in the present generation because in a class there is a large diversity of learners in every class. By this we can individualize the approaches."

Theme \#11: Teaching is constant assessing

A Mathematics teacher maintains that teaching entails constant assessing of performance of students to be able to gauge the speed of progress. One Business Management professor even emphasizes that assessment should also consider the primacy of attendance of students because according to him, it is still important for students to understand the subject matter discussed.

\section{Theme \#12: Teaching is enjoying}

Teaching needs not be boring and lifeless. It should be vibrant and dynamic. It should be enjoyable to students. As a scholar once said,

\begin{abstract}
"Students learn more when they enjoy". This is also the belief of a nursing professor who puts it, "Learning must be enjoyable and fruitful to learners." An IT instructor corroborates this by saying, "I think there should be an emphasis on the gamification of teaching for the students to understand their lessons."
\end{abstract}

Theme \#14: Teaching is effective managing

Teaching calls for effective management. As a Hospitality Management instructor elaborates,

\begin{abstract}
"Curriculum should be managed in accordance with school activity schedules levents, so it won't compromise [teaching]."
\end{abstract}

Theme \#14: Teaching is believing

To top all these, teaching is believing. An Education professor rightfully comments, "I believe that teaching is the noblest of all professions. As such, new/future educators should be aware of the given responsibility of being a mentor." All actions begin with the thought-the mind. As a physicist once said, "For every action there is always a cause." Teaching is like that. If it starts from an iota of belief that teaching can make the world a better place, then, this world can be a better place to live in through the actions people make as consequence of that belief. If a teacher believes that his/her teaching will change the life of his/her students, then, everything will follow.

\section{Conclusion and Implications}

This study was able to identify not only the degree of the school's qualities based on ten highly effective schools but also the teachers' beliefs and views. By integrating the data, it augurs a number of realizations: There is a seamless connection between the teachers' perceived traits of the institution as a highly effective college and the teachers' views about the interview questions.

Except in research trait, teachers perceived the college as having very-to-strong traits of highly effective schools. Said perceptions are corroborated by the teachers' views expressed during interview.

These include the following: a) teachers believe that professional growth should be achieved and provided for by the institution; their desire to improve research skills put into practice is worth noting; b) apart from their desire for professional growth, teachers believe they can help realize the College's vision, mission and core values through various activities such as doing research, community outreach activities, fulfilling their duties as faculty, and advocating good governance. Teachers succinctly explain the strategies to help the institution realize its vision, mission, and objectives and core values; and c) the teachers envision the institution's graduates as those who are locally and globally competitive, competent, empowered and gainfully employed; research-oriented, competent leaders, and virtuous graduates.

We can surmise that the teachers' beliefs, perspectives and aspirations are the same the qualities they think could help improve the quality of education in the institution. When we say improvement of quality education, we mean not only leveling up from Level 1 to Level 11 status in accreditation but also continuously demonstrating and upgrading the tenets of a highly effective college. Apparently, these are also the teachers' perspectives of quality education. As stated in EQAO paper, teachers' beliefs could be the teachers' definition of their future expectations of the institution. As Davis and Andrzejewski [10] put it: Teachers' beliefs shape their professional practice because these beliefs emanate from personal experiences, and probably from their professional experiences.

The fourteen themes exhibit various facets of teaching beliefs as experienced by teachers. Despite the differences of perspectives and beliefs, the themes also reflect unity in diversity. Teachers have 
their own distinct perspectives about teaching, but still the trajectory of these beliefs is towards achieving quality education. The themes emerged show how wisdom penetrated the mindset of teachers, expressed through their beliefs and perspectives. The ways a teacher's role is practiced is best understood by his beliefs [17]. This implies further researches on the topic because as the research implicitly reveals, the wisdom about teaching continuously evolves throughout time and in every context. As beliefs and perspectives evolve with experience and context, teaching also continues to metamorphose but its essence remains to be perpetually untarnished.

Finally, the interweaving of teacher beliefs, perspectives and aspirations could be the framework of teachers' concept of and in improving of quality education. In short, quality education concept is shaped according to the context teachers are in and as a consequence of the activities they have experienced. This implies that in improving the quality of education, the teachers should not be forgotten but the involvement of the stakeholders is imperative. Students and other stakeholders should be involved in this study to validate the responses and views of the teachers. The study suggests using the idea of School that Learn by Senge et al. [21]. Its concept is on Learning Orientation. It means involving everyone in the system in expressing their aspirations, building their awareness, and developing their capabilities together.

\section{Acknowledgements}

This study is funded by the St. Dominic College of Asia Faculty Development Fund. The authors would like to thank Dr. Gregorio Andaman Jr., the SDCA president for the support, the faculty members for their participation and Anton Albuladora for editing the manuscript.

\section{References}

[1] Angell, B., and Townsend, L., Designing and conducting Mixed Methods Studies, ww.sswr.org/

Designing and Conducting Mixed Methods Studies.pdf. (Access date: 20 August 2013).

[2] Bahry, S. A., (2012). What Constitutes Quality in Minority Education? Front. Educ. China 2012, 7(3): 376$\wedge 16$ DOI 10.3868/S110-001-012-0021-5.

[3] Boon, H., (2011). Raising the Bar: Ethics Education for Quality Teachers. Journal of Teacher Education. Volume 36, Issue7, Article 6.

[4] Chai, C.S., Teachers' Epistemic Beliefs and their pedagogical beliefs: A Qualitative Case Study among Singaporean Teachers in the Context of ICT-Supported Reforms. The Turkish Online Journal of Educational
Technology - October 2010, volume 9 Issue 4http://www.weizmann.ac.il/weizsites/blonder/files/20 11/02/EJ908079 (Access date: 02 October 2013).

[5] Robson, C., (2011). Real World Research (3rd edition). A John Wiley and Son, Ltd. Pur. UK pg. 165.

[6] Creswell, J. W., PlanoClark, V. L., Guttman, M., Hanson, W., (2003). Advanced Mixed Methods Research Designs. In: A. Tashakkori \& C. Teddlie (Eds.), Handbook on Mixed Methods in the Behavioral and Social Sciences, pp. 209-240. Thousand Oaks, CA: Sage Publications.

[7] Davis, H., and Andrzejewski, C., Teachers' Beliefs. Updated on Dec 23, 2009 Copyright 2003-2009 The Gale Group, Inc. http://www.education.com/reference/ article/teacherbel iefs/. (Access date: 02 September 2013).

[8] Defining Quality in Education. A paper presented by UNICEF at the meeting of The International Working Group on Education Florence, Italy .June 2000. Working Paper Series Education Section United Nations Children's Fund New York, NY, USA http://www.unicef.org/education/files/QualityEducati on.PDF. (Access date: 01 August 2013).

[9] Education Quality and Accountability Office Ontario (EQAO), http://www.eqao.com/EQI/ EQI_Framework. (Access date: 02 June 2013).

[10] Griffiths, T., Gore, J., and Ladwig, J., Teachers' fundamental beliefs, commitment to reform, and the quality of pedagogy. The University of Newcastle. Paper prepared for presentation at Australian Association for Research in Education Annual Conference Adelaide, November 26-30, 2006.

[11] Hehir, T., and Katzman, L., (2012). Effective Inclusive Schools . Designing Successful Schoolwide Programs. Jossey-Bass. A Wiley Imprint. USA.

[12] Hoofman, A. M., and Spangehl, S.D., (2012) Innovations in Higher education. American Council on Education. Rowman and Littlefield Publishing Inc. United Kingdom

[13] Hulpia, H., Geert, D., and Van Keer, H., The Influence of distributed Leadership on Teachers' Organizational Commitment: A Multilevel Approach. Higher Education Review

[14] McEwan, E. K., (2009). 10 Traits of Highly Effective Schools. Raising the Achievement Bar for All Students. Corwin Press. A SAGE Company. California, USA.

[15] Imran, M., (2008). A Comparative of Quality Education of Education Public and Private secondary schools of Punjab, http://www.prr.hec.gov.pk/ Thesis/385S.pdf, (Access date: 2 October, 2013).

[16] Northcote, M., Educational Beliefs of Higher Education Teachers and Students: Implications for Teacher Education. Australian Journal of Teacher Education. Volume 34 Issue 3 Article 3.2009 
http://ro.ecu.edu.au/cgi/viewcontent.cgi (Access date: 02 September 2013)

[17] Spanneberg, R., (2007). Teachers' Beliefs and Practices related to a Professional Development Programme in South African Rural Schools. Rhodes University Mathematics Education Project, South Africa. www.aare.edu.au/01pap/spa01178.htm (Access date: 02 August 2013)

[18] Senge, P.M., (1990). The fifth discipline: The Art and Practice of the Learning Organization. New York: double day/currency.

[19] OECD, (2009). "What are teachers' beliefs and practices?", in Highlights from Education at a Glance 2009, OECD Publishing. http://dx.doi.org/

10.1787/eag_highlights-2009-36

[20] Valli, L., and Buese, D., (2007). The Changing Roles of Teachers in an Era of High-Stakes Accountability. American Educational Research Journal. September 2007, Volume 44, number 3, pp.519-558. DOI:10.3102/0002831207306859.Copyright

AERA 2007.

http://aerj.aera.net (Access date: 02 September 2013). 